\section{RESULTS}

A two-way analysis of the variance on the speed data on Trial 3 tested for effects due to dissonance, delay of reinforcement, and their interaction. There was no dissonance effect or interaction between dissonance and delay of reinforcement. No evidence of dissonance induction was found since dissonance drive induction did not manifest itself as superiority of dissonance over control groups regardless of delay. Only the delay of reinforcement effect was significant $(F=4.28, \quad \mathrm{df}=2 / 138, \quad \mathrm{p}<.025)$ Tukey's test on the means of each level of delay showed that the 0 -sec delay group responded significantly faster than both the 3- and 8-sec groups, but there was no difference between the 3-and 8-sec delay groups.

A three-way analysis of the variance tested for acquisition and higher-order interactions effects. The acquisition effect was highly significant $(F=34.44, \mathrm{df}=2 / 276, \mathrm{p}<.001)$, and the Delay of Reinforcement by Trials interaction $w$ as also significant $(\mathrm{F}=3.52, \mathrm{df}=4 / 276, \mathrm{p}<.01)$. No other effects were significant. The acquisition curves appear in Fig. 1

\section{DISCUSSION}

The results indicated that negative reinforcement due to reduction of cognitive dissonance added nothing to positive reinforcement due to good scores. Therefore, only the good scores presented following the instrumental response actually served to reinforce that response. A trials effect, delay of reinforcement effect, and a Delay by Trials interaction effect due to positive reinforcement were obtained. Delay of positive reinforcement combined multiplicatively with the number of reinforced trials to determine the speed of responding.

Other research has investigated the effects of performance expectancy upon performance (Cottrell, 1967; Zajone \& Brickman, 1969). Zajonc and Brickman showed that although Ss' reaction times were energized by dissonant feedback information, mere estimation of expected performance led to acquisition. Mere estimation of expected performance cannot account for either the delay of reinforcement effect or the Delay by Trials interaction effect obtained here.

Cottrell found that expectancy-performance dissonance reduction was limited to judgmental processes. Ss did not adjust their performance (reaction time) to reduce dissonance but did reject inconsistent information about their performance by changing their estimates of their task proficiency.

Most importantly, the purpose of this experiment was to relate cognitive dissonance theory to Hull-Spence theory. It seems likely that the tailure to obtain delay of dissonance reinforcement effects lies in the inaccuracy of dissonance theory, since the more conventional good-score positive reinforcements functioned as in conditioning theory, and some studies have failed to replicate the Aronson and Carlsmith effect (e,g. Brock, Edelman, Edwards, \& Shuck, 1965; Lowin \& Epstein, 1965).

\section{REFERENCES}

ARONSON, $E$. The theory of cognitive dissonance: A current perspective. In L. Berkowitz (Ed.) Aduances in experimental social psychology. Vol. 4. New York: Academic Press, 1969 Pp. 2-34.

ARONSON, E.. \& CARLSMITH, J. M. Performance expectancy as a determinant of actual performance. Joumal of Abnormal \& Social Psychology, 1962, 65 178-182.

BROCK, T. C. EDELMAN, S. $K$ EDWARDS, D. C., \& SHUCK, J. R. Seven studies of performance expectancy as a determinant of actual performance Journal of Experimental Social Psychology, 1965, 1, 295-310.
COTTRELL. N. B. The etferts of dissonance between ispected and obtained performance upon task erstimates of tash of tash proficiency. Journal of Socia Psv chology, 1967, 72, 275-284.

COTTRELL, N. B. \& WACK, D. L Energizing effects of cognitive dissonance upon dominant and subordinate responses. Journal of Personality \& Social Psychology, 1967, 6, 132-138

FOWLER, H., \& TRAPOLD. M. A. Escape performance as a function of delay of reinforcement. Journal of Experimental Psychology, 1962, 63, 464-467.

LOWIN, A., \& EPSTEIN, G. F. Does expectancy determine performance? Journal of Experimental Sorial Psy chology, 1965, 1, 248-255

WATERMAN, $C$. $K$. The facilitating and interfering effects of cognitive dissonance on simple and complex paired associates tasks. Journal of Experimental Social Psychology, 1969, 5, 31-42.

WATERMAN, C. K., \& KATKIN, E Energizing (dvnamogenic) effects of cognitive dissonance on task performance. Journal of Personality \& Social Psychology, 1967, 6, 126-131.

ZAJONC, R. B., \& BRICKMAN, P Expectancy and feedback as independent factors in task performance. Joumal of Personality \& Social Psychology. 1969 $11,148-156$

\title{
Impression change and favorableness of first impressions: A study of population and of commitment effects*
}

\author{
STEPHEN T. MARGULIS, University of Florida, Gainesville, Fla. 32601 \\ PHILIP R. COSTANZO, Duke University, Durham, N.C. 27706 \\ and \\ ANDREW L, KLEIN, Tulane University, New Orleans, La. 70112
}

The present study replicated and extended Briscoe, Woodyard, \& Shaw's (1967) study of impression formation. The replication yielded overall recency effects and did not find that initially unfavorable first impressions were more resistant to change. This failure to replicate was not due to initial differences in impressions and was attributed to hypothesized population differences. The extension, on commitment, indicated that commitment was greatest for Ss who made covert initial ratings and least for those who made public initial ratings. The commitment effects were related to Kiesler's (1968) commitment theory.

Briscoe, Woodyard, \& Shaw (1967) presented college $S s$ with two prescaled descriptions, one favorable (F) and one unfavorable (U). They found the UF order of descriptions

*Thanks to John Dibler, Sunnyland Boy Scout Council Executive, and David Dickson and George Keuel, District Executives, whose assistance and cooperation made this study possible. Thanks, too, to the Scoutmasters and boys of Camp Flying Eagle, Sarasota, Florida. 1968 camp season. more resistant to change than the FU order. Furthermore, the interpolated mode ( $S$ evaluates after each description) and FU order favored a recency effect, the final mode ( $S$ evaluates after reading both descriptions) and UF order favored a primacy effect, and both other combinations produced neutral final evaluations. The results were in accord with earlier studies (e.g., Anderson \& Barrios, 1961). 
This study replicated Briscoe et al, with a younger population, in order to assess the external validity (Campbell \& Stanley, 1963) of their findings, and additionally considered whether or not manipulated commitment would affect the resistance of first impressions to change. In this regard, research (e.g., Deutsch \& Gerard, 1955) suggests that a public commitment should be more resistant than an anonymous one, and both should be more binding than only private reflection on one's initial impression. Thus, it was predicted that within the UF order, the greater the commitment, the less favorable the final impression, and within the FU order, the greater the commitment, the more favorable the final impression.

\section{SUBJECTS}

The Ss were 151 Boy Scouts attending summer camp. Scouts 11-13 years old outnumbered Scouts 14-16 years old by $2: 1$. This approximates the age distribution of Scouts in general (Survey Research Center, 1960). An approximate 2:1 ratio was maintained in all cells.

\section{MATERIALS}

A presentation of materials can be found in Briscoe et al (1967, p p. 346-347). However, their descriptions were modified slightly for younger Ss. The measure of impressions was the sum (or mean) on six scales, loading at least .75 or higher on the evaluative dimension of the semantic differential (Shaw \& Wright, 1967). (Briscoe et al used four scales from the evaluative dimension. Two scales were used in common.)

\section{DESIGN}

The overall design, five treatment conditions crossed with two orders of descriptions, can best be conceived of as two separate (overlapping) designs. Each of these designs consists of three treatment conditions crossed with two orders of description. (This format is presented in Table 1.) One design, a replication of Briscoe et al (and labeled Replication Conditions in Table 1), consists of four experimental and two control conditions. The anonymous mode, an example of what Briscoe et al call the interpolated mode, required Ss to read one description of the person, evaluate the person, then read the second description and rate the same person again. The final mode required $S s$ is evaluate the person described after having read both descriptions of him. Control Ss receive only one description. In the present study, control Ss rated the description only once; Briscoe et al had their control Ss rate the single description twice. The temporal placement of the control Ss' evaluation in the present study was equivalent to the second rating by control Ss in Briscoe et al. While anonymous Ss did initial (Time 1) ratings, final and control condition $\mathrm{Ss}$ cancelled letters. While experimental Ss read the second description, control Ss cancelled letters.

The second design (labeled Commitment Conditions in Table 1) consists of three examples of the interpolated mode of responding. Ss were assigned to one of three commitment conditions, through written instructions, just prior to their initial (Time 1) ratings. Public commitment Ss expected that their ratings, which they were to sign, would be collected (and presumably studied) by the Scout supervisor. Anonymous commitment Ss were told that, since ratings would be collected, Ss were to remain anonymous. (The anonymous condition is part of both designs and appears twice in Table 1 to a id the presentation.) Reflect commitment Ss were told to "really think" about and to note mentally their initial impressions on the rating scales. Furthermore, there was no mention of collecting ratings. PROCEDURE

There were 20 separate sessions, one for each condition each week. Each week represented a new group of Scouts. The E was a Scout leader and the assistant director of the camp. The time spent on each page of the test booklet was fixed (but sufficient), and Ss were not permitted to look ahead or back in their booklets.

\section{RESULTS}

Unplanned, unequal cell frequencies required unweighted-means ANOVA procedures; the a posteriori test was the Newman-Keuls procedure (Winer, 1962). A two-tailed $5 \%$ level established statıstical significance. Impression Change

No differences were found between the present control rating and Briscoe et al's Time 1 and Time 2 control ratings within Control $F$ and within Control U conditions. This suggests no "change" in the present control group ratings. Although both anonymous conditions did show impression change, when comparing anonymous UF and FU conditions, there were no significant effects of order of descriptions on impression change. This held for both mean change and for proportion of change (i.e., actual change divided by maximum possible change). In sum, the present results do not replicate Briscoe et al's finding of greater resistance to change of UF, compared with FU, orders of descriptions.

\section{Primacy-Recency Effects}

Anderson \& Barrios's (1961) criteria for primacy-recency (Briscoe et al, 1967 , p. 350) was used. In this study, unlike Briscoe et al, overall recency effects were found. Unweighted-means ANOVA of Time 2 ratings of al. experimental groups reveals effects due to order of descriptions ( $F=56.6$. $\mathrm{df}=1,109, \mathrm{p}<.0005$ ) and Order by Mode $(F=8.0, \mathrm{df}=3,109, \mathrm{p}<.0005)$. This interaction does not resemble that of Briscoe et al. Newman-Keuls tests show that anonymous UF ratings were more favorable than anonymous FU ratings $(p<.01)$ and that final UF ratings were more favorable than final FU ratings $(p<.05)$. (There were no other significant comparisons.)

Effects of Commitment

Since Time 1 ratings in the public and anonymous conditions were equivalent (i.e., $F<1$, except for expected $U$ vs $F$ differences), Time 2 ratings were used. The predicted ordering of Time 2 means (where " $>$ " = "more favorable") was: UF order, reflect $>$ anonymous $>$ public; FU order, public $>$ anonymous $>$ reflect. However, the exact opposite, in both cases, was obtained (see Table 1). Newman-Keuls tests suggest the ordering within both orders is not due to chance. UF order: public more favorable than both anonymous $(p<.05)$ and reflect $(p<.01) ; F U$ order: public less favorable than reflect $\quad(p<.01)$. No other comparisons were significant. Hence, the commitment predictions, as stated, are disconfirmed.

Population Differences

There was a direct comparison of Scouts with the male Ss $(30$ college students, 18-25 years old) run by Briscoe et al. 1

The two populations were found to be initially equivalent (except for obvious differences between descriptions). This held for comparisons of control group ratings (see impression change, above) and for comparisons of control ratings (Briscoe Time 1 and present control rating) with comparable anonymous (interpolated, in Briscoe et al) Time 1 ratings, within and across both populations.

Means for the anonymous/ interpolated and final conditions, for both populations, are given in Table 1 . The three factors in the unweighted-means ANOVA of Time 2 ratings were population, order of descriptions, and mode of responding. There were significant effects for population $(\mathrm{F}=16.8, \mathrm{df}=1,70$ $\mathrm{p}<.0005)$, order $(F=6.4$, df $=1,70$, $\mathrm{p}<.025$ ), Population by Order $(F=6.4, \quad$ df $=1,70, \quad p<.025), \quad$ and Mode by Order $(F=4.5, \mathrm{df}=1,70$, $\mathrm{p}<.05)$. By inspection, Scouts and UF order each produced more favorable final impressions. This was also reflected in the interactions. Newman-Keuls tests show that Scouts' 
Table 1

Mean Rating Score on the Impression Formation Task as a Function of Order, Commitment, and Population

\begin{tabular}{|c|c|c|c|c|c|c|}
\hline \multirow[b]{2}{*}{ Condition } & \multirow[b]{2}{*}{ Order } & \multicolumn{2}{|c|}{ Boy Scout Ratings 1} & \multicolumn{2}{|c|}{ Male College Ss1,2 } & \multirow[b]{2}{*}{$\mathbf{N}$} \\
\hline & & Time 1 & Time 2 & Time 1 & Time 2 & \\
\hline \multicolumn{7}{|c|}{ Replication Conditions } \\
\hline Anonymous & UF & 2.55 & 5.25 & 2.15 & 3.70 & 16 \\
\hline Anonymous & FU & 6.27 & 3.54 & 6.35 & 2.80 & 16 \\
\hline Final & UF & & 5.23 & & 3.05 & 11 \\
\hline Final & FU & & 4.09 & & 3.95 & 15 \\
\hline Control & $\mathbf{U}$ & & 2.78 & 2.75 & 2.70 & 17 \\
\hline Control & $F$ & & 6.47 & 6.10 & 5.80 & 17 \\
\hline \multicolumn{7}{|c|}{ Commitment Conditions (Interpolated Mode) } \\
\hline Public & UF & 2.57 & 6.13 & & & 14 \\
\hline Anonymous & UF & 2.55 & 5.25 & & & 16 \\
\hline Reflect & $\mathrm{UF}$ & & 4.68 & & & 12 \\
\hline Public & $\mathbf{F U}$ & 6.28 & 3.03 & & & 14 \\
\hline Anonymous & $\mathbf{F U}$ & 6.27 & 3.54 & & & 16 \\
\hline Reflect & $\mathrm{FU}$ & & 4.37 & & & 19 \\
\hline
\end{tabular}

1.Means can range from 1 (most unfavorable) to 7 (most fauorable); neutral is 3.5. Based on semantic differential scales, evaluative dimension.

2 Data from Briscoe, Woodyard, \& Shaw $(1967) ; N=5$ per cell.

UF ratings were more favorable than each of the other three means in the Population by Order interaction $(p<.01)$. This implies a recency effect for Scouts and neither primacy nor recency effects for college males. Anonymous/Interpolated FU ratings were less favorable than each of the other three means in the Mode by Order interaction $(p<.01)$. This implies a recency effect in the interpolated mode and neither primacy nor recency effects in the final mode. (All other comparisons were nonsignificant.) In sum, the overall population differences reflect the overall recency effect among Scouts.

\section{DISCUSSION}

The present findings were unexpected, and, since there was no attempt made in either study to assess population characteristics (other than age), unrooted speculation will be held to a minimum. For example, there is no easy explanation for greater resistance to change of UF, compared to FU, orders of descriptions for college-aged males but not for younger Boy Scouts. Research by Wrightsman \& Cook (1965), which shows formal similarities with the present designs, suggests that personal philosophy (e.g., cynicism) may be involved.
As for Scouts' final impressions and population differences (i.e., Population by Order, Mode by Order interactions), these are a consequence of antonymic information, not of any initial differences in impressions, and of the resulting recency effects among Scouts. Unfortunately, what is known about the effects of stimulus presentation factors on primacy-recency effects cannot bring conceptual order to these findings (e.g., Bramel, 1969). For exmaple, even college Ss display overall recency effects under certain conditions (Anderson, 1968; Rosenbaum \& Levin, 1968). In all, the present results suggest limits on the external validity of Briscoe et al's results.

Last, the effects of commitment, though unexpected, are consistent with Kiesler's (1968) theory of commitment. He reports that, as the justification for an action increases, resistance to its change (i.e., commitment) decreases. Whereas public Ss may feel coerced (i.e., high justification) because of signing ratings which $\mathbf{E}$ will collect and read, reflect Ss share none of these coercions (i.e. low justification). It follows that public Ss are less committed and should change more than reflect Ss. The results agree with this analysis and additionally suggest conditions under which a private commitment may be more binding than a public commit ment.

AN

\section{ANDERSON REFERENCES}

i A ${ }^{2}$. Application of a $1 \mathrm{mode} t \mathrm{t}$ personality-impression task using serial presentation. Joumal of Personality \& Social Psychology, 1968, 10, 354-362.

ANDERSON, N. H., \& BARRIOS, A. A Primacy effects in personality impression formation. Journal of Abnormal \& Social Psychology. 1961.63, 346-350.

BRAMEL. D. Determinants of beliefs about other people. In J. Milis (Ed.) Experimental social psychology. New York: Macmillan, 1969. Pp. 77-107.

BRISCOE, M. E., WOODYARD, H. D., \& SHAW, M. E. Personality impression change as a function of the favorableness of first impressions. Journal of Personality, 1967, 35, 343-357.

CAMPBELL, D. T., \& STANLEY, I. C Experimental and quasi-experimental designs for research on teaching. In N. L Gage (Ed.). Handbook of research on teaching. Chicago: Rand-McNally, 1963. Pp. 171-246.

DEUTSCH, M., \& GERARD, H. B. A study of normative and information social influences upon individual judgments. Journal of Abnormal \& Social Psychology, 1955, 51,629-636.

KIESLER, C. A. Commitment. In R. P. Abelson et al (Eds.). Theories of cognitive consistency: $A$ sourcebook. Chicago: Rand-MaNally, 1968. Pp. 445-455.

ROSENBAUM, M. E., \& LEVIN, I. P. Impression formation as a function of source credibility and order of presentation of contradictory information. Journal of Personality \& Social Psychology. 1968, 10, 167-174.

SHAW, M. E., \& WRIGHT. J. M. Scales for the measurement of at titudes. New York: McGraw-Hill, 1967.

SURVEY RESEARCH CENTER. A summary of a studv of Boy Scouts and their Scoutmasters. Institute for Social Research, University of Michigan, January 1960 .

WINER, B. J. Statistical principles in experimental design. New York: McGraw-Hill, 1962.

WRIGHTSMAN, L. S. \& COOK, s. W. Factor analysis and attitude change. Paper presented at Southeastern Psychological Association convention. Atlanta, April 1965. Cited in L. S. Wrightsman, Annotated bibliography of research on the Philosophies of Human Nature Scale, 1969 revision. Unpublished manuscript. George Peabody College for Teachers, December 1969. NOTE

1. We wish to thank Marvin E. Shaw for graciously lending us the original data from their study. 